\title{
Solid ANd Living: The Italian Woolf RENAISSANCE
}

\author{
Elisa Bolchi
}

$\mathrm{I}^{\mathrm{N}}$

N HER INTRODUCTION TO THE vOlume The Reception of Virginia Woolf in Europe, Nicola Luckhurst poses a stimulating question for scholars of reception studies: 'Is this multiple and iconic Virginia Woolf at the beginning of the twenty-first century the conclusion of the writer's reception in Europe?' (2002: 17). Drawing from this question, this chapter ${ }^{1}$ shows how, far from fading with time, Woolf's iconic status in Italy has continued to grow into what I call an 'Italian Woolf Renaissance'. Furthermore, the chapter aims to highlight the relevance of local reception histories by identifying and evaluating those factors and agents which shape the reception of Woolf in non-Englishspeaking literary traditions: not only professional readers, publishers and scholars, but also common and passionate readers as well, to whom Woolf has been able to address.

The first to examine Virginia Woolf's fortune in Italy in the twenty-first century was Sergio Perosa, with his essay 'The reception of Virginia Woolf in Italy' (2002), in which he made a quick survey of the Italian translations of Woolf and of the Italian literary journals in which her work was discussed. A more specific analysis of the writer's reception in periodicals came out in my own 2007 book Il paese della bellezza. Virginia Woolf nelle riviste italiane tra le due guerre [The Country of Beauty. Virginia Woolf in Italian Literary Periodicals between the Two World Wars], which not only analysed her early reception in Italy, but also gathered the transcription of all the articles that had appeared in Italian journals from 1927 - when the first article on Woolf appeared in the Corriere della Sera [The Evening Gazette] - to the end of the Second World War. When Alessandra Scalero's Italian translation of Orlando was released by mainstream publisher Mondadori in 1933, twelve articles surveying Woolf's novels and essays had already appeared in leading literary periodicals. ${ }^{2}$ In this first phase of Woolf reception, her prose was often read by critics with a sense of reverence 'only similar to what one feels in front of ancient beauty', ${ }^{3}$ as Umberto Morra wrote (1928: 27). Most interestingly, Italian scholars have continuously focused their attention on three crucial aspects of Woolf's prose: form, character-creation and the psychological aspects of her narration.

The editorial aspects of Woolf's Italian publication were analysed in my 2015 book L'indimenticabile artista. Lettere e appunti sulla storia editoriale di Virginia Woolf in Mondadori [The Unforgettable Artist. Letters and Notes on the Editorial History of Virginia Woolf in Mondadori] (Bolchi 2015a). By means of the documents preserved at the Mondadori's Historical Archive, the book examines Woolf's Italian publication up to the 1960 s to understand the editorial dynamics which had put her works in the Italian literary marketplace. Her reception actually suffered a 
contraction in the aftermath of the Second World War, when publishers and readers were more interested in politically engaged fiction with a neorealistic approach. Yet, after this postwar phase, a resurgence of popular interest in her work took place in concomitance with the rise of feminism in Italy.

After a reception characterised by alternating phases, Virginia Woolf has been enjoying a renewed and growing attention in Italy in the last decade, an attention which started when her publication rights expired in 2011, thus allowing greater access for the retranslation and republication of her work. As this chapter will show, once Woolf's works were in the public domain, their publication in Italy was characterised by three main paths: the retranslations of her most important novels by prestigious publishers like Giulio Einaudi Editore, the translations of works that had never been translated before and the appearance of refined editions of her books in the catalogues of small, independent publishers. The competent translators and scholars who edited some of these volumes have helped Italian readers to better understand Woolf's prose, and have ushered in her Italian Renaissance.

Having as its focus the recent popularisation of Woolf icon in Italy, this study does not take into account her critical reception, either in scholarly essays or in periodicals and newspapers, but concentrates instead on the agents who play fundamental roles in the distribution of an author within the marketplace: publishers, translators and, of course, readers. Specifically, the editorial projects that came after the expiration of Woolf's translation rights in 2011 are the focus; interviews were thus the preferred tool of investigation to gather information from publishers and translators, and the recent founding of the Italian Virginia Woolf Society in 2017 has made it possible to tentatively characterise Italian readers of Woolf. In this Italian Renaissance, independent publishing houses such as Nuova Berti, Nottetempo or Racconti edizioni play a role similar to that of the Modern Library series in the United States; in fact, as Lise Jaillant explains, the US series not only widened Woolf's audience but it also allowed her books 'to cross the gap between common and professional readers' (2014: 83).

Readers have indeed played a fundamental role in the Italian Woolf Renaissance. Virginia Woolf herself gave readers a crucial role by claiming that independence is 'the most important quality that a reader can possess' (E 5: 573), thus positioning common readers outside the dependency of highbrows' reviews or judgement to read and appreciate a work. As she wrote in 'How should one read a book?': 'the only advice, indeed, that one person can give another about reading is to take no advice, to follow your own instincts, to use your own reason, to come to your own conclusions' (E 5: 573). Woolf wrote for, and addressed her essays to, the common reader and, as Jaillant notes, she 'wrote for popular magazines such as Vogue, she was published by the commercial publishing firm Harcourt, Brace, and some of her books sold widely to a middle-class audience. In other words, Woolf willingly participated in middlebrow culture' (2014: 94). Yet most scholars have viewed her 'as an archetypical highbrow writer, without questioning a label which dates from the interwar period' (Jaillant 2014: 94). It was Melba Cuddy-Keane who presented Woolf as 'an advocate for both democratic inclusiveness and intellectual education' (2003: 1), a perception that describes the contemporary reception of Woolf in Italy. By means of interviews with recent translators and publishers of Woolf's works and of an analysis of their reception in the Italian cultural network (reading public, web, artistic field), I elucidate the reasons why Italians' fascination for Woolf is growing horizontally among cultural and age groups, social classes, and professional and common readers. 


\section{The Mondadori Trust}

Although the catalyst for renewed interest in Woolf was the above-mentioned expiration of her publication rights in 2011, a step back is necessary to thoroughly understand how this interest developed. To that end, I discuss the original Italian translations of Woolf by her historic publisher, Arnoldo Mondadori Editore.

The first of Woolf's novels to be translated in Italian was Orlando (1933), published as part of the newly created Medusa series. This series, directed by Luigi Rusca for the Mondadori publishing house, was devoted entirely to foreign contemporary fiction, for which they envisaged only 'élite translators' (Scalero 1932a). In 1934, two other novels by Woolf appeared in Italy: Fratelli Treves published To the Lighthouse in the Scrittori Stranieri Moderni series, translated by Giulia Celenza with an introduction by the renowned scholar Emilio Cecchi, while Mondadori published Flush, again in the Medusa series and translated by Alessandra Scalero. But the translation of Woolf's novels soon had to stop because of the harsh cultural climate of fascism. The Regime's propaganda, exalting manliness and patriarchal ideals, would not have welcomed the publication of novels such as Mrs Dalloway, which explores a woman's psyche and portrays a distraught shell-shocked veteran who commits suicide. ${ }^{4}$ Towards the end of the Second World War, however, Mondadori hastened to buy the foreign rights for many authors, including Virginia Woolf, whose translation rights he bought with an agreement dated 31 December 1944. The Mondadori Press seemed more interested in acquiring the publication rights, which they considered to be 'the only true wealth of a publisher' (Mondadori 1945a), ${ }^{5}$ than in actually publishing the works they had bought. The translator Alessandra Scalero noted this in her first encounter with the publishers and wrote to her sister: 'it seems that Mondadori, with inconceivable arrogance, is buying out all the foreign market; they did unpleasant things, they stepped on other publishers' toes even grabbing the authors, a true trust' (Scalero 1932b). ${ }^{6}$ Alberto Mondadori's project was ambitious: he wanted to publish the complete works of Woolf in an Opera Omnia edited by the renowned scholar Emilio Cecchi, and he wrote to Leonard Woolf claiming to be 'especially interested in the critical books', which he wanted to prioritise (Mondadori 1945b). The difficulties were many, however. First and foremost was the problem of translators, because Italian intellectuals who knew English well enough to translate Woolf were rare at the time and both Alessandra Scalero and Giulia Celenza had died prematurely. Mondadori had to overcome several other obstacles; some of the commissioned translations never came back, for instance, and so these circumstances led to him abandoning his project to publish Woolf's Opera Omnia. Those 'critical books' that Mondadori wanted to prioritise were not published until nineteen years after the signing of the agreement, in a significantly reduced edition titled Per le strade di Londra [Street Haunting: A London Adventure] (Woolf 1963). ${ }^{7}$ What is more, the collection was not published by Mondadori but by the publishing house that Alberto, Arnoldo Mondadori's son, had founded in 1958, Il Saggiatore. Italian readers had to wait until 2012 - when the volume Voltando pagina [Turning a Page], edited by Liliana Rampello for Il Saggiatore was published - to read a more exhaustive, although still incomplete, collection of Woolf's essays (Woolf 2012).

A first wave of (re)publication of Woolf started in 1975, when the independent feminist press La Tartaruga bought the rights to Three Guineas, and a second wave took place in 1991, when the rights, which lasted fifty years from the death of the author, first expired. The duration of rights was, however, soon extended to seventy 
years, so that Mondadori once again became the owner of the Italian rights until 2011, when they eventually expired.

\section{Who's Not Afraid to (Re)translate Woolf?}

As a matter of fact, Mondadori's monopoly on Woolf rights had ended many years before 2011. Einaudi publishing house had bought the rights to Woolf's diaries and letters in the 1970s, but published only five of the six volumes of letters and never published the diaries; although they were entirely translated by Bianca Tarozzi, only one volume with a selection of pages from 1925 to 1930 was released by the publisher Rizzoli in 2012. In 1992, on the wave of retranslations that followed the first expiration of publication rights in 1991, Nadia Fusini translated To the Lighthouse for the publisher Feltrinelli, changing the Italian title from Gita al faro [A Trip to the Lighthouse] to the more faithful Al Faro, because, as she noted in her introduction,

that to is a preposition that in English does not simply indicate a preposition of movement. . . . It is also a dative: the pole of an offer, of a gift. Virginia Woolf thus writes for the Lighthouse: addressing that light. And thanks to that light. And what she writes for that light becomes her present to it. (Fusini 1992: 7) ${ }^{8}$

In 1993 Fusini also translated and edited a new edition of Mrs Dalloway for Feltrinelli; in 1995 she made a new translation of The Waves for Einaudi, in the prestigious Scrittori tradotti da scrittori [Writers translated by writers] series founded by Italo Calvino; and in 1998 she edited Woolf's works for Mondadori's canonizing series Meridiani.

When the duration of rights was extended from fifty to seventy years, Einaudi and Feltrinelli were forced to stop their projects of retranslating Woolf. They had to wait until 2012, when Einaudi published a new translation of Mrs Dalloway by Anna Nadotti, the Italian translator of both A. S. Byatt, a writer with clear modernist influences, and Anita Desai, described by Nadotti herself as a 'very Woolfian writer' (Nadotti 2017). Einaudi also planned to retranslate James Joyce's Ulysses, which had been published by Mondadori in 1960 and translated by Giulio De Angelis, and whose rights had expired in the same year as Woolf. However, while Joyce came out in the Letture series, an expensive collection addressing highbrows and scholars more than the 'common reader', Einaudi proposed that Mrs Dalloway be published in the Classics section of the Tascabili series, a paperback collection of the texts that was part of the university canon, including authors such as Jane Austen, Robert Louis Stevenson and Leo Tolstoy. Nadotti was delighted with this decision because, she said, 'when I was at university, Virginia Woolf was not part of the canon yet, and the idea of being the person in charge of translating her prose for a canonical collection filled me with pride' (Nadotti 2017). Moreover, the books from this collection were to include authoritative introductions. According to Nadotti, the introduction was especially important for the reintroduction of Mrs Dalloway to Italian readers. Nadotti asked the writer and poet Antonella Anedda to introduce Mrs Dalloway so that the final editorial product might represent a door through which Italian readers could (re)enter and (re)discover the novel. The translation was published in June 2012; by the end of September it had run out of stock. Einaudi made a first reprint in October, but a third reprint was needed for the annual book fair the following May. Three reprints in under a year for 
an eighty-seven-year-old novel, already available to the public in several other editions, is a considerable success in a country in which 59.5 per cent of the population have not read a book in one year ('La lettura' [Book reading] 2016). This success led Einaudi to ask Nadotti for a new translation. To the Lighthouse was selected, and this novel once again was received with great approval, although it is curious that the 'old' title Gita al faro was chosen over the new title Al faro that was selected by Fusini in 1992. The novel was another success, as testified by the fact that it was turned into a summer marketing tool: every summer, Einaudi creates a beach towel with an illustrated quote from a classic novel, and in summer 2018 it was the turn of Nadotti's translation of To the Lighthouse, which readers could get by buying two novels in the Tascabili series. ${ }^{9}$

While the two retranslations by Einaudi are examples of the publisher proposing a new translation of Woolf to a competent translator, Feltrinelli's new edition of The Years represents a different scenario, one in which it was the translator who proposed a republication of the work. The editor-in-chief of Feltrinelli's collection of classics had told the Italian scholar Antonio Bibbò about their need to fill some editorial gaps in their catalogue and asked him to think of some canonical authors to translate. Bibbò proposed five novels, two of which were enthusiastically accepted: Woolf's The Years and Daniel Defoe's Moll Flanders. Woolf was the first to be translated and published, and Gli Anni [The Years] went out at the beginning of 2015, selling more than 3,400 copies in two years. Once again Woolf's iconic status was affirmed by a marketing campaign launched by Feltrinelli. By buying two novels of the Universale Economica (the paperback series), readers could get a throw reproducing the cover design of Gli anni. From beach towels to fleece blankets Woolf actually seems to be 'a woman for all seasons'.

Bibbò admitted to feeling 'a debt' towards The Years: 'Among Woolf's novels this is the last I have discovered, and a reason for such a delay was the oblivion into which the novel had fallen after the first successful months, not only in Italy' (Bibbò 2017). ${ }^{10}$ Bibbò admitted to being both enchanted and frightened by it:

it seemed to me, and it still does, that it is one of Woolf's most sincere novels, the most human, in which she faces not only the limits of existence, but also some of her most evident limits as a writer, such as that of rarely abandoning the representation of an upper-class London environment. (Bibbò 2017) ${ }^{11}$

Bibbò was afraid of not being able to reproduce the 'never cloying elegance of the novel', ${ }^{12}$ noting how

The Years does not have poetic prose like The Waves, it is a city novel, often discordant and prosaic; it tries, more than any other of Woolf's texts, to plunge into the filthiness of society while never renouncing careful control of tone and register, which is never vulgar. The internal musicality, the continuous cross-references between the pages and the phrases spoken and played with by different characters are less mechanical than in other more modernist novels; they have the spontaneity of daily speech, of family sayings, and I wanted to render such spontaneity at all costs without the result sounding mechanical. (Bibbò 2017) ${ }^{13}$

Woolf's prose was also held in awe by two other translators, Francesca Cosi and Alessandra Repossi. In 2012 they translated extracts from the early diaries of Woolf, 
and in particular the pages she wrote while she travelled in Italy, Greece and Turkey, which had never before been translated into Italian. Cosi and Repossi admitted that their translation of Woolf is the one of which they are most proud and they translated her pages with a sort of 'reverential fear' (Cosi and Repossi 2017), given that Woolf had always been one of their personal idols. ${ }^{14}$ When asked why they chose to translate her travel journals, although Woolf was certainly not a travel writer, they answered:

At first we did not think about her travels; in studying the juvenile writings of Woolf in search of unpublished pages, however, we thought that the most interesting texts were these diaries. ... [T]hey ... were a true training ground for her writing, extremely rich in reflections on other literary texts, on writing and also, of course, with suggestions deriving from the places she had been visiting. Travelling in these pages is, for Woolf, almost a pretext to test her own talent: she is searching not for descriptive but for evocative writing. . . . It's true that Woolf's name is not commonly associated with travel, but in this case the travel is the stimulus that induces her to find new ways to tell the truth. (Cosi and Repossi 2017) ${ }^{15}$

Probably because of these 'new ways to tell the truth', this collection offered readers the possibility of reading Woolf from a new perspective. The translators at first only envisaged publishing the travel diaries in Italy, Greece and Turkey, but the book was such a success that the publisher asked them to put together other books from Woolf's diaries: Qui è rimasto qualcosa di noi [There is Something of Our Own Preserved Here] in 2012, the diaries of her travels in Great Britain, and Ultimi viaggi in Europa [Last Travels in Europe] in 2013. The success of these books is demonstrated by the fact that in 2016 they were reprinted in a three-volume paperback edition and titled Diari di viaggio in Italia e in Europa [Travel Diaries in Italy and Europe]. The publisher of these diaries, Mattioli 1885, is a small but historical publisher who prints an average of fifty titles per year. Independent publishers like Mattioli 1885 have played the most active role in the Italian Woolf Renaissance, as I go on to show in the next section.

\section{Independent Publishers' Gift to Woolf}

Independent publishers benefited the most from the expiration of the publication rights of Woolf's works in 2011 because they were finally able to include her in their catalogues. If these editions played a crucial role in the Italian Woolf Renaissance it is, first of all, because they facilitated more widespread reading of Virginia Woolf. Similarly to what happened with Woolf's participation in the American Modern Library series, her publication in the catalogue of independent publishers exemplified 'her positioning as a democratic writer who wrote for the intelligent common reader' (Jaillant 2014: 84). The appearance in the market of these small volumes, often presenting collections of essays, allowed Italian readers to no longer be afraid of Virginia Woolf because they were allowed to enter into her prose from different, sometimes secondary, doors that might offer easier access. Most of these editions are small but sophisticated volumes in lively handy format - 'solid objects', as in Woolf's short story (Woolf 1977). Many of the translators and publishers I interviewed described their work in terms of a gift from Italian intellectuals to Virginia Woolf. This approach to her prose is also perceived as new by the Italian community of Woolf's readers, who are (re)discovering Woolf through these new editions and through the words of the new editors. 
One of these solid objects is the collection Lunedì o Martedi, a translation of Monday or Tuesday published in 2012 by Nuova Editrice Berti. I interviewed the director of the publishing house Cecilia Mutti, who told me that she had always loved Woolf and that she 'liked the idea of re-proposing her to the Italian public with Monday or Tuesday, Woolf's only collection of short stories to be published while she was still living' (Mutti 2017). Mutti was fascinated by the project because it was a 'domestic publishing project of the Hogarth Press, with a cover design by Vanessa Bell and a conspicuous series of typos that made Leonard furious', and she also was amused by this because 'after all, we are a small publishing house too, with an almost domestic dimension’ (Mutti 2017). ${ }^{16}$

This volume was followed by a translation of Granite and Rainbow. As Mutti explains,

presented with a graphic design recalling the original one by Vanessa, these essays, in which Woolf moves between solid-as-granite facts and the weightless flash of the rainbow, are tangible proof that a lucid, pleasant-to-read and vivid literary criticism can exist. It is wonderful how this book is also loved by young boys and girls who, even though they are not looking for academic reads, probably fascinated by the title, or by the handy format, buy this book and find themselves with a hidden gem in their hands. (Mutti 2017) ${ }^{17}$

Cecilia Mutti's words are particularly interesting if read in the light of Mondadori's decision not to buy the translation rights of the collection when it was published in 1958 because it was considered by Elio Vittorini to be a 'needless expenditure' (Vittorini 1958), given that these were pages that had been discarded by Leonard Woolf. However, because Mondadori did not want other publishers to issue a volume of essays by Woolf before they had published those already in their possession, they agreed with Leonard that he could sell the rights of Granite and Rainbow only after Mondadori had published a collection of essays. The first collection of essays by Woolf was only published in 1963 though, and since no publisher showed an interest in Granite and Rainbow in the following years, the collection remained unpublished until 2013. After Granito e arcobaleno, Nuova Editrice Berti also published Anon and Reading at Random as very refined editorial projects: a small and handy format, a matte cover with nineteenth-century illustrations in pale blue and straw-coloured pages, whose layout is enriched by Demetrio Costa's drawings. When Costa was asked to illustrate Anon, he discovered that Woolf mentioned Thomas Malory in her essay, and since he had a fascination for Aubrey Beardsley's illustrations of Malory's Morte d'Arthur, he took inspiration from Beardsley's style to draw chapter initials, inspired by the Goudy Mediaeval Regular font, which was designed in England in the 1930s. For the decorations he put together Beardsley's illustrations, with their Eastern and Pre-Raphaelite elements, and flowers and plants. 'I read that the idea of writing Anon came to Woolf while she was harvesting blackberries, so I made long walks myself, picking blackberries and making jams, thinking about my drawings', ${ }^{18}$ Demetrio Costa explains, and in thinking about his drawings he 'tried to imagine the visual worlds which had nourished Woolf's words; those words are images themselves' (2017). ${ }^{19}$ The books are translated and edited by Massimo Scotti, whose introductions are essential to guide the reader into Woolf's prose. 'The quality (and peculiarity) of the texts forced me to make an adequate edition', Scotti comments, 'since the book represented an unicum also inside 
Woolf's authorial macrotext, notes and introduction were fundamental, and I kept taking notes while I translated so I wouldn't get lost' (2017). ${ }^{20}$ Scotti dedicated almost a year and a half to the translation of the few pages of Anon, equally dividing his time between translation, notes and introduction, and this is the reason why he considers it 'a sincere homage to Virginia' (2017). ${ }^{21}$ These uncommon, less canonical texts are helping to present a new portrait of Woolf to the Italian common reader, showing her multiplicity, her flexibility, her ability to be a modernist writer with a strong sense of tradition and, most important, her contribution to forming a new tradition of female writing. The development of her writing skills and of her literary talent is also displayed to the public in the complete collection of short stories, recently published by another independent Italian publishing house, Racconti Edizioni.

The complete short stories had already been translated and published in Italy by the small yet historic publishing house La Tartaruga, which was the first to publish Three Guineas in 1975, thus launching Woolf's feminist thought in Italy. The collection of short stories had, however, been out of stock for years, meaning that they were only readable as e-books until 2016. Stefano Friani and Emanuele Giammarco, who had just founded Racconti Edizioni as a publishing house devoted to short stories, felt there was 'an undeniable and compelling call'22 to reissue Woolf's short-stories (Friani 2017); they were edited by the renowned critic Liliana Rampello, with the suggestive title Oggetti solidi [Solid Objects]. Woolf's short stories are the seventh volume in their catalogue and 1,300 copies were printed - a considerable number for a new-born independent publisher in a country in which the publishing market is in crisis. The book was unexpectedly out of stock in two weeks; a reprint ran to 1,000 copies, which also sold out, so that it went through a third reprint in less than a year, becoming their bestseller.

\section{The Italian Woolf Community}

Such a proliferation of new editions of Woolf's works proved the existence of a community of Woolf readers in Italy, of people sharing a passion for, an interest in and a knowledge of Woolf. It is a community similar to what Étienne Wenger defined as a 'community of practice', that is 'a group of people who share a concern, a set of problems, or a passion about a topic, and who deepen their knowledge and expertise in this area by interacting on an ongoing basis' (Wenger et al. 2002: 4). It was not until February 2017, when I founded the Italian Virginia Woolf Society together with Nadia Fusini, Liliana Rampello and Iolanda Plescia, that I could fully realise how real and strong such a community of Italian readers and scholars of Woolf existed. As Wenger et al. affirm: "communities of practice are the ideal social structure for "stewarding" knowledge. ... [T] hese communities provide a social forum that supports the living nature of knowledge' (2002: 12), and we had this idea in mind when we decided to institutionalise the Italian community of Woolf readers and scholars. As a matter of fact, if it was possible to create an Italian Virginia Woolf Society, it was because a community already existed and just needed an 'intentional and systematic organization about managing knowledge' (Wenger et al. 2002: 6). Proof of this was the fact that the Italian Virginia Woolf Society received membership requests as soon as it was founded, and these have never stopped. Academics, actors, writers and common readers alike 
soon joined the Society not to be part of an institution, but to share knowledge, concerns and interest in Woolf. 'Though our experience of knowing is individual, knowledge is not' (Wenger et al. 2002: 10), and that is why it was fundamental to base the making of the Society on a multi-way channel: scholars share their knowledge of experts and readers shared their knowledge of passionate apprentice. In three years from its foundation, the Italian Virginia Woolf Society counts 190 members and has a website (Italian 2017), a Twitter profile, an Instagram account and a Facebook page with more than 4,000 followers; and public events have been organised in Rome, Turin, Bologna, Milan and other smaller cities, each attended by hundreds of people.

The web and social networking services have been fundamental in the creation and development of the Society. While during the earliest period of its development the web 'functioned as a reading vehicle, a digital forum where information prevailed and communication was one-way' now it has 'evolved into a socialization platform, which holds a vast store of knowledge deriving from the large amount of research and innovation produced through the talent, imagination, audacity, and intelligence of the network's users' (Lóper-Pérez and Olvera-Lobo 2016: 243). Web users handle information differently than they used to do ten years ago, and this mainly derived from the advent of social media, the so-called Web 2.0, the users of which have grown from 970 million in 2010 to 2.62 billion in 2018 ('Number' 2019). Social media are user-centred, open, participatory, interactive and they are (or should be) places for knowledge sharing. Indeed, thanks to social media the web was transformed into a new public space for citizen participation, and Facebook has become 'one of the most popular tools for sharing, commenting on, and posting new content' (Ciftci and Knautz 2016: 116). Interactivity and the exchange of information are part of social media's nature and therefore represented the perfect 'forum' for our community.

Among the definitions provided by Wenger et al., I particularly cherish the one in which they explain how

communities of practice do not merely manage knowledge assets. They create value in multiple and complex ways, both for their members and for the organization. ... '[S]ome ... of their greatest value lies in intangible outcomes, such as the relationships they build among people, the sense of belonging they create, the spirit of inquiry they generate, and the professional confidence and identity they confer to their members. (2002: 15)

This was the aspect we hoped to enhance by creating an Italian Virginia Woolf Society and this is what we can, proudly, claim to have attained. In cooperation with Raffaella Musicò, the owner of a bookshop significantly called Virginia e co., the Italian Virginia Woolf Society organises 'Il faro in una stanza' [The lighthouse in a room], an annual festival dedicated to Woolf. The festival takes place on the last weekend of November three days in which writers, scholars and translators are invited to speak on Woolf to a wide audience. Although the first four festivals took place in Monza and Sesto San Giovanni, two towns near Milan, they enjoyed an enthusiastic participation: events were fully booked, with people queuing to buy entrance tickets. Dozens of national newspapers, journals and blogs dedicated articles to the festival and people came from all over Italy to meet and listen to people talking about Woolf. Apart from showing 
a cultural interest in the writer, the festival contributes to build those relationships among people and that 'sense of belonging' to which Wenger et al. refer.

The aim of the Italian Virginia Woolf Society is also to gather, both physically and virtually, readers, scholars and teachers interested in Woolf for personal or scholarly reasons. A tangible effect of this is the fact that the community can represent a useful tool for surveying Woolf readers in Italy, to discover more about them and their reading habits - for example, how old they are, when they started to read Woolf and which work they started with. I thus created six short questions regarding their gender, their age, the first book they read by Woolf, when they read it, who suggested or recommended it and how many books by Woolf they have read. To test the relevant role social media can have as tools not only to communicate scientific results but also to gather data for research, also at an academic level, ${ }^{23}$ the survey was disseminated through the Society's Facebook and Twitter pages on 28 June 2018, and it was closed after twenty days. The survey was completed by 444 people: 85.2 per cent of readers were women, while only 14.6 per cent were men; and their ages were mainly between twenty and thirty-five years, mirroring the average age of Facebook users ('Distribution' 2019). When I looked at this sample in detail, however, I saw interesting aspects.

The first question regarded gender and it was no surprise to have fewer than 15 per cent male readers, given that Woolf has often been considered by Italian public as a writer who mainly addresses women. Interestingly, though, a closer analysis of the data shows that almost 47 per cent of the male respondents had read more than five books by Woolf, and 22 per cent of this 47 per cent had read more than ten books by Woolf. Given that the corresponding percentage of women who had read more than ten books by Woolf was 19 per cent, this percentage is not just very similar, it is slightly higher. It thus proves that, once introduced to readers, Virginia Woolf speaks equally to women and men, and gives rise to an interest in her work regardless of the reader's gender.

In her essay 'Hours in a library', Woolf wrote that 'the great season for reading is the season between the ages of eighteen and twenty-four' $(E$ 2: 55). This seems to be partially true for Woolf readers in Italy as well: almost 45 per cent of respondents affirm that they read Woolf for the first time before turning 25, thus confirming Woolf's statement. This is curiously truer in men (55.4 per cent) than in women (42.4 per cent). However, the survey does reveal that readers who discover Woolf before the age of eighteeen are mainly women (32.5 per cent compared to 16.9 per cent of men).

One of the most interesting aspects that emerged from the sample was the fundamental role played by school in introducing Woolf to Italian readers. Those who first read Woolf at school or at university represent the vast majority of Woolf readers (48.7 per cent); interestingly, though, the absolute majority is represented by the 32.1 per cent who first read Woolf at secondary school, whereas only 16.6 per cent were introduced to her at university, exactly the same percentage as those who were introduced to Woolf by friends. The results regarding the role of magazines and newspapers are also interesting because they demonstrate that these media played a slightly more important role than family in introducing Woolf to readers (6.7 per cent versus 6.2 per cent). Surprisingly, fewer than 1 per cent were introduced to Woolf by films (two mention Sally Potter's Orlando and only one The Hours). If we then compare this data with that of the number of Woolf's books read by each respondent, we discover that more than 50 per cent of those who were introduced to Woolf at school have read one to four 
books by her, while only 11 per cent have read more than ten books. This percentage increases for those who first read Woolf at university to 18.6 per cent. This seems to suggest that school is valuable for introducing Woolf to Italian readers, but it is not enough to create lifelong Woolf lovers. The highest percentage of people reading more than ten books by Woolf was those who got to her independently, through personal choice.

If we then consider which of Woolf's books are read, in first place we have Mrs Dalloway with 28.2 per cent, while To the Lighthouse is in third place with 23 per cent. This is easily explained by the fact that they are the texts usually included in school anthologies. In second place we find A Room of One's Own with 24.3 per cent. This text is usually included in university programmes, and the high percentage of people for whom it was the introductory text to Woolf confirms the importance of her iconic status as a feminist in Italy. ${ }^{24}$ Orlando, which was the first novel translated into Italian, comes in only in fourth place in this sample, with 12.7 per cent, followed by A Writer's Diary (3.6 per cent) and The Voyage Out (3.2 per cent).

Because this chapter mainly focuses on the most recent years of Woolf's status in Italy, specifically the period after 2011, the group of youngest readers (under 20 years old) is particularly worth analysing, even though they represent only 1.8 per cent of the sample, probably because Facebook and Twitter are not the favoured social networks of 'Generation Z' ('Number' 2019). The data shows that there is no clear tendency in this group of readers: considering their young age, one would imagine that almost all of them were introduced to Woolf by a schoolteacher, but only 25 per cent confirm this expectation. The remaining 75 per cent mention a newspaper article, a bookseller or a member of the family. It is also worth noting that, in this group, the first novel to be read was not Mrs Dalloway but To the Lighthouse, followed by Orlando.

\section{New Artistic Impulses}

Having concentrated on the reading of Virginia Woolf in Italy, I conclude by mentioning two examples of the re-reading of her works. The interlinguistic one is actually not the only translation of Woolf in Italy; some of her works, like Orlando, Room and the letters between Woolf and Vita Sackville-West, have been adapted for the stage, and Room has also inspired a children's book titled Una stanza tutta per me [A Room of My Own] (2017), written by Serena Ballista and illustrated by Chiara Carrer. In 2018, Woolf was the object of two exhibitions that were not simple retellings of her works. In fact, the artists Piera Benetti and Gloria Bertolone used Woolf's novels, specifically Mrs Dalloway and The Waves, as ingredients to create their own works of art.

From 11 February to 11 March 2018, Spazio Oberdan in downtown Milan hosted an exhibition by the Italian painter Piera Benetti. Titled Nelle cose [Inside Things], it represented the First World War on the Italian mountains of Lavarone, Trentino, through the eyes of Septimus Warren Smith and the language of Virginia Woolf. The captions of the abstract paintings were passages from Mrs Dalloway. 'We wanted to show Septimus's intimate dialogue, to let it flow parallel to the paintings' ${ }^{25}$ the artist told me when I interviewed her:

He thinks and looks; when he raises his eyes it is the places of war he sees, not Milan, the city seen by Rezia. In the same way the visitors, after having read the 
captions (displaying without interruption the pages of Woolf's novel), raise their eyes and see not what Septimus saw in his mind, but what we see today in visiting those places. (Benetti 2018) ${ }^{26}$

One of the most fascinating aspects of the exhibition was the colours of the paintings: bright, light, joyful colours, quite the opposite of what one would expect from an exhibition on the First World War. I asked Benetti the reason for this choice and she answered: 'I chose colour as my language. I could perhaps say that the colour in my paintings is like Mrs Dalloway's flowers, like Rezia's straw hats, what cannot be overlooked, what cannot be postponed, what we should start from' (Benetti 2018). ${ }^{27}$ The artist Gloria Bertolone, by contrast, used photos, texts and videos for her exhibition Sulle onde. I Fell in Love with Virginia Woolf. Inspired by The Waves, it took place in Genoa, at the Theatre-museum Commenda from 26 July to 9 September 2018. The project was the result of the artist's deep passion for the novel and it is the realisation of many years of study. As Bertolone explains:

the works follow the pace of Virginia Woolf's text and develop in the time frame between the first and the tenth interlude; in the middle, the immensity and the charm of soliloquies. Renouncing for the first time the representation of the human body, I completely abandoned myself to the visions of the landscapes of the soul that the writer gave us and that have rested in me. ('Sulle onde' 2018) ${ }^{28}$

Such an adaptation of Virginia Woolf by Italian artists to portray Italian landscapes and feelings is indeed indicative not only of the iconic status that the writer has reached in the Peninsula, but of her active role in inspiring and encouraging new artistic productions. And is there a better symbol of Renaissance than a new drive for artistic development and expression?

\section{Notes}

1. The writing of this article was supported by funding from the European Union's Horizon 2020 research and innovation programme under the Marie Skłodowska-Curie grant agreement No. 838658.

2. For example, Carlo Linati presented her in the pages of Il Corriere della Sera on 24 January 1927 and reviewed A Room of One's Own in the journal Leonardo in 1930; and Umberto Morra, who, along with writing a long article in the journals Il Baretti in 1928 and La Cultura in 1931, reviewed Orlando in Solaria in 1929 and The Waves in Pègaso in 1932. The renowned writer Sibilla Aleramo reviewed Orlando in the journal L'Italia Letteraria in 1931.

3. 'Simile solo a quello che si prova davanti alla bellezza antica.' All translations mine unless otherwise indicated.

4. Evidence for this is provided in letters that Rusca wrote to Woolf's translator, Alessandra Scalero (Rusca 1940); see Bolchi (2015b).

5. Alberto Mondadori wrote in a memo for the President: 'I diritti restano e sono l'unica autentica ricchezza dell'editore.'

6. 'Pare che Mondadori, con una boria da non dirsi, si stia accaparrando tutto il mercato straniero, hanno fatto delle cose poco simpatiche, pestando i piedi agli altri editori accaparrandosi gli autori addirittura, un vero trust.' Alessandra Scalero used the word 'trust' 
in English. The two sisters often used foreign words (German, French, English) in their correspondence when they thought they were more 'emphatic' or meaningful in a language other than Italian.

7. The collection presented twenty-one essays: four from the First Common Reader, four from the Second Common Reader, seven from The Death of the Moth, five from The Moment and Other Essays, plus A Room of One's Own.

8. 'Quel to è preposizione che in inglese non indica semplicemente un moto a luogo. ... È anche un dativo: il polo di un'offerta, di un dono. Virginia Woolf scrive per il Faro, dunque: rivolta a quella luce. E grazie a quella luce. E ciò che scrive per quella luce, anche glielo dona.'

9. The quote is taken from 'The window' at the end of Chapter 10: 'Girandosi, guardò al di là della baia, e laggiù, certo, scivolando a intervalli regolari sulle onde, prima due lampi veloci, poi uno lungo e durevole, c'era la luce del Faro. L'avevano acceso.' [Turning, she looked across the bay, and there, sure enough, coming regularly across the waves first two quick strokes and then one long steady stroke, was the light of the lighthouse. It had been lit.]

10. 'È il romanzo di Woolf che ho scoperto più tardi e mi sono reso conto che uno dei motivi di questa mia tardiva scoperta è stato proprio il sostanziale oblio nel quale questo romanzo è caduto dopo i primi trionfali mesi, non solo in Italia.'

11. 'mi sembrava, e mi sembra tutt'ora, che sia uno dei libri più sinceri di Virginia Woolf, uno dei più umani, in cui la scrittrice non solo affronta i limiti dell'esistenza, ma anche alcuni dei suoi più evidenti limiti di scrittrice, come quello di uscire raramente dalla rappresentazione di un certo ambiente londinese benestante e alto-borghese'.

12. 'l'eleganza mai stucchevole del romanzo'.

13. 'Y non ha una prosa poetica come $W$, è un romanzo cittadino, spesso stridente e prosaico, cerca, più di altri testi di Woolf, di affondare nel basso corporale e nel sudiciume della società ma sempre senza rinunciare a un controllo molto attento sul tono e sul registro, che non è mai volgare. La musicalità interna, i continui rimandi tra le pagine e tra le frasi simili pronunciate e masticate da personaggi diversi sono meno meccanici che in altri romanzi più volontariamente modernisti; hanno la naturalezza delle parole quotidiane, degli scambi del lessico familiare e volevo a tutti i costi rendere quella naturalezza senza risultare meccanico.'

14. In addition to my interview with them in June 2017, see Lucius Etruscus (2011) for part of the story of the Italian translation of Woolf's travel diaries.

15. 'All'inizio non avevamo in mente il viaggio; studiando gli scritti giovanili di Woolf alla ricerca di inediti, però, ci è sembrato che i testi più interessanti fossero proprio questi diari: ... erano delle vere e proprie palestre di scrittura, ricchissime di riflessioni su altri testi letterari, sulla scrittura stessa e anche, ovviamente, di suggestioni dei luoghi attraversati. Il viaggio in queste pagine è per Woolf quasi un pretesto per mettere alla prova il proprio talento: è alla ricerca di una scrittura che non descriva ma che evochi. . . . È vero che il nome di Woolf non è comunemente associato al viaggio, ma in questo caso il viaggio è lo stimolo che la induce a trovare nuovi modi di raccontare la realtà.'

16. 'un progetto editoriale nato in famiglia, alla Hogarth Press, con la copertina disegnata dalla sorella Vanessa e una serie incalcolabile di errori tipografici che avevano fatto infuriare il marito Leonard, mi divertiva molto: in fondo anche noi siamo una piccola casa editrice, con una dimensione quasi famigliare'.

17. 'sono la dimostrazione tangibile che possa esistere una critica letteraria viva, e lucida, e piacevole da leggere. È bello che questo libro sia molto apprezzato anche dai ragazzi più giovani, che, pur non essendo in cerca di letture accademiche, forse affascinati dal titolo, o dal formato esile privo di apparati, si trovano per le mani una perla sconosciuta'.

18. 'Ho letto che l'idea di scrivere Anon era venuta a Virginia Woolf mentre andava in cerca di more, quindi ho fatto anch'io lunghe passeggiate, molte raccolte di more e molte marmellate, pensando a come avrei fatto i miei disegni.' 
19. 'cercavo di immaginare quale fosse il mondo visivo che aveva nutrito le sue parole; quelle parole stesse sono immagini'.

20. 'si tratta in qualche modo di un unicum anche all'interno del macrotesto autoriale woolfiano; introduzione e note erano irrinunciabili, e prendevo appunti mentre traducevo, per non disperdermi'.

21. 'Un sincero omaggio a Virginia.'

22. 'era una chiamata irresistibile e irrinunciabile'.

23. As asserted by Lourdes Lóper-Pérez and María Dolores Olvera-Lobo (2016), Johanna Ross (2012), and Gemma Nández and Ángel Borrego (2013), among others.

24. It would, however, be intriguing to discover what role the publication of A Room of One's Own in the very economic series ' 1000 lire' by the publisher Newtown Compton played in this.

25. 'Abbiamo pensato di mostrare il dialogo intimo di Septimus a di farlo correre parallelamente ai quadri.'

26. 'Lui pensa e guarda, quando alza lo sguardo vede i luoghi della guerra, non vede Milano, la città che vede Rezia. Così il visitatore dopo aver letto le didascalie (che riportano senza interruzione due intere pagine del romanzo della Woolf) alza lo sguardo e vede. Non quello che vedeva nella sua mente Septimus ma quello che oggi si vede visitando quei posti.'

27. 'Ho scelto il colore come linguaggio. Il colore nei miei quadri potrei forse dire che è come i fiori di Mrs Dalloway, come le pagliuzze di Rezia quello da cui non si può prescindere, quello che non si può mettere dopo ma con cui forse sarebbe meglio cominciare.'

28. 'le opere seguono a stralci l'andamento del testo di Virginia Woolf e si sviluppano nell'arco di tempo compreso tra il primo e il decimo interludio, in mezzo, l'immensità e la malia dei soliloqui. Rinunciando per la prima volta alla raffigurazione del corpo umano mi sono abbandonata totalmente alle visioni dei paesaggi dell'anima che la scrittrice aveva regalato e che mi erano restati dentro.'

\section{Bibliography}

Aleramo, S. (1931), 'Orlando inglese' [English Orlando], L'Italia letteraria, 42, pp. 8-9.

Ballista, S. (2017), Una stanza tutta per me [A Room of My Own], Cagli: Settenove.

Benetti, P. (2018), email interview, 19 March.

Bibbò, A. (2017), email interview, 9 June.

Bolchi, E. (2007), Il paese della bellezza. Virginia Woolf nelle riviste italiane tra le due guerre [The Country of Beauty. Virginia Woolf in Italian Literary Periodicals within the Two World Wars], Milan: EDUCatt.

Bolchi, E. (2015a), L'indimenticabile artista. Lettere e appunti sulla storia editoriale di Virginia Woolf in Mondadori [The Unforgettable Artist. Letters and Notes on the Editorial History of Virginia Woolf in Mondadori], Milan: Vita e Pensiero.

Bolchi, E. (2015b), “La Woolf è scrittrice difficile e ci vuol dei traduttori coscienziosi”. Le vicende traduttive delle prime edizioni italiane di Virginia Woolf' ['Woolf is a difficult writer and we need diligent translators'. The background of the Italian translations of Woolf], Testo a fronte, 53, pp. 87-106.

Ciftci, T. and K. Knautz (2016), 'Information literacy levels of Facebook users', in Knautz and K. S. Baran (eds), Facets of Facebook. Use and Users, Berlin: De Gruyter, pp. 115-45.

Cosi, F. and A. Repossi (2017), email interview, 21 June.

Costa, D. (2017), 'Illustrazioni per un Anonimo' [Illustrations for Anon], Giacomo Verri libri, 20 March, <https://giacomoverri.wordpress.com/2017/03/20/6574/> (last accessed 18 January 2019). 
Cuddy-Keane, M. (2003), Virginia Woolf, the Intellectual, and the Public Sphere, New York: Cambridge University Press.

'Distribution of Facebook users worldwide as of October 2018, by age and gender' (2019), Statista, <http://www.statista.com/statistics/376128/facebook-global-user-age-distribution/> (last accessed 29 January 2019).

Etruscus, L. (2011), 'Francesca Cosi \& Alessandra Repossi', Thriller Magazine, 7 November, $<$ http://www.thrillermagazine.it/11660/francesca-cosi-and-alessandra-repossi> (last accessed 31 July 2018).

Friani, S. (2017), email interview, 6 June.

Fusini, N. (1992), 'Introduzione' [Introduction], in V. Woolf, Al faro, Milan: Feltrinelli, pp. 7-30.

Italian Virginia Woolf Society (2017), <http://www.itvws.it> (last accessed 2 June 2019).

Jaillant, L. (2014), Modernism, Middlebrow and the Literary Canon: The Modern Library Series, 1917-1955, London: Pickering and Chatto.

'La lettura in Italia' [Book reading in Italy] (2016), Istituto Nazionale di Statisca (Istat), <https:// www.istat.it/it/archivio/178337> (last accessed 2 June 2019).

Linati, C. (1927), 'Virginia Woolf', Il Corriere della Sera, 24 January, p. 3.

Linati, C. (1930), 'Virginia Woolf - A room of one’s own', Leonardo, 3, pp. 175-6.

López-Pérez, L. and M. D. Olvera-Lobo (2016), 'Social media as channels for the public communication of science: The case of Spanish research centers and public universities', in K. Knautz and K. S. Baran (eds), Facets of Facebook: Use and Users, Berlin/Boston, MA: De Grutyer, pp. 241-64.

Luckhurst, N. (2002), 'Introduction', in M. A. Caws and N. Luckhurst (eds), The Reception of Virginia Woolf in Europe, London: Bloomsbury, pp. 1-18.

Mondadori, A. (1945a), 'Memo for the President', Miscellanea Arnoldo Mondadori, B. 12 f. 5 (Esilio Svizzera), Fondazione Arnoldo e Alberto Mondadori, Archivio Storico Arnoldo Mondadori Editore. Milan: not dated (but probably June 1945).

Mondadori, A. (1945b), 'Letter to Leonard Woolf', Virginia Woolf, Fondazione Arnoldo e Alberto Mondadori, Archivio Storico Arnoldo Mondadori Editore. Milan: 15 November 1945.

Morra, U. (1928), 'Virginia Woolf', Il Baretti, 5, p. 27.

Morra, U. (1929), 'Virginia Woolf - Orlando: A Biography', Solaria, 5, pp. 50-6.

Morra, U. (1931), 'Il nuovo romanzo inglese. Virginia Woolf' [The new English novel. Virginia Woolf], La Cultura, 1, pp. 34-51.

Morra, U. (1932), 'The Waves', Pègaso, 3, pp. 377-80.

'Most popular social networks worldwide as of October 2018, ranked by number of active users (in millions)' (2019), Statista, <http://www.statista.com/statistics/272014/global-social-networks-ranked-by-number-of-users/> (last accessed 29 January 2019).

Mutti, C. (2017), email interview, 7 June.

Nadotti, A. (2017), phone interview, 10 June.

Nández, G. and A. Borrego (2013), 'Use of social networks for academic purposes: A case study', The Electronic Library, 31: 6, pp. 781-91.

'Number of social media users worldwide from 2010 to 2021' (2019), Statista, <https://www. statista.com/statistics/278414/number-of-worldwide-social-network-users/> (last accessed 30 January 2019).

Perosa, S. (2002), 'The reception of Virginia Woolf in Italy', in M. A. Caws and N. Luckhurst (eds), The Reception of Virginia Woolf in Europe, London: Bloomsbury, pp. 200-17.

Ross, C. (2012), 'Social media for digital humanities and community engagement', in C. Warwick, M. Terras and J. Nyhan (eds), Digital Humanities in Practice, London: Facet Publishing, $<$ https://blogs.ucl.ac.uk/dh-in-practice/chapter-2/> (last accessed 28 January 2019).

Rusca, L. (1940), 'Letter to Alessandra Scalero', ref. 6.01.03, Fondo Scalero, Civica Biblioteca di Mazzè. Mazzè: 5 November. 
Scalero, A. (1932a), 'Letter to Liliana Scalero', Fondo Scalero, Civica Biblioteca di Mazzè. Mazzè: 1 December.

Scalero, A. (1932b), 'Letter to Liliana Scalero', Fondo Scalero, Civica Biblioteca di Mazzè. Mazzè: 28 November.

Scotti, M. (2017), email interview, 6 June.

'Sulle onde': Alla Commenda la mostra ispirata al romanzo più rivoluzionario della Woolf' ['On the Waves': An exhibition inspired by Woolf's most revolutionary novel at the Commenda Theatre] (2018), Goa Magazine, 25 July, <http://www.goamagazine.it/sulle-onde-alla-commenda-la-mostra-ispirata-al-romanzo-piu-rivoluzionario-della-woolf/> (last accessed 30 January 2019).

Vittorini, E. (1958), 'Note for the head director', Virginia Woolf, SEE 77/43, Fondazione Arnoldo e Alberto Mondadori, Archivio Storico Arnoldo Mondadori Editore. Milan: 11 July.

Wenger, E., R. McDermott and W. M. Snyder (2002), Cultivating Communities of Practice: A Guide to Managing Knowledge, Boston, MA: Harvard Business School Press.

Woolf, V. (1963), Per le Strade di Londra ['Street Haunting: A London Adventure'], trans. L. Bacchi Wilcock and J. R. Wilcock, Il Saggiatore: Milan.

Woolf, V. (1977 [1944]), A Haunted House and Other Short Stories, Harmondsworth: Penguin.

Woolf, V. (1986-2010), The Essays of Virginia Woolf, ed. A. McNeillie (vols 1-4) and S. N. Clarke (vols 5-6), 6 vols, San Diego: Harcourt.

Woolf, V. (2012), Voltando Pagina [Turning a Page], ed. L. Rampello, Il Saggiatore: Milan. 